\title{
Obinutuzumab, a potent anti-B-cell agent, for rituximab-unresponsive IgM anti-MAG neuropathy
}

Goran Rakocevic, MD, FAAN, Ubaldo Martinez-Outschoorn, MD, and Marinos C. Dalakas, MD, FAAN

Neurol Neuroimmunol Neuroinflamm 2018;5:e460. doi:10.1212/NXI.0000000000000460

Anti-MAG demyelinating neuropathy is difficult to treat. All immunotherapies have failed except for rituximab, a chimeric B-cell-depleting monoclonal antibody against CD20, that helps up to $40 \%$ of patients based on 2 controlled and several uncontrolled series. ${ }^{1-3}$ Because the majority of these patients are left disabled, stronger anti-B-cell agents might be promising.

We describe clinical response and autoantibody changes after treatment with obinutuzumab (Gazyva), a new generation of humanized anti-CD20 monoclonal antibodies, in 2 patients with anti-MAG neuropathy who continued to worsen despite multiple courses of rituximab. Obinutuzumab, approved for chronic lymphocytic leukemia (CLL), exerts greater peripheral and lymphoid B-cell depletion ${ }^{4}$ and might be more effective in rituximab-refractory patients.

\section{Classification of evidence}

This is a single observational study without controls and provides Class IV evidence that obinutuzumab is safe to use in patients with IgM anti-MAG demyelinating neuropathy.

\section{Patients and treatments}

\section{Patient 1}

A 71-year-old man developed feet paresthesias that progressed in 4 years to bilateral foot drop.

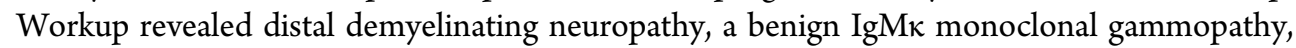
elevated IgM levels, and high-titer anti-MAG antibodies (table). The gammopathy was benign including normal bone marrow biopsy. He received 3 monthly courses of IVIG without benefits. Rituximab, $2 \mathrm{~g}$, was ineffective without affecting the IgM level or anti-MAG titers while his weakness continued to worsen. Obinutuzumab was then administered in 6 cycles over 6 months, as per the CLL protocol, as follows: day 1: $100 \mathrm{mg}$; day 2: $900 \mathrm{mg}$; days 8 and 18: $1,000 \mathrm{mg}$ each; and 1,000 mg thereafter monthly for 5 months.

\section{Patient 2}

A 65-year-old man, developed distal leg numbness and paresthesias 13 years ago following successful therapy for colorectal cancer. The neuropathic symptoms gradually worsened with sensory ataxia and muscle weakness. Workup revealed a demyelinating neuropathy, an IgMk gammopathy, normal bone marrow biopsy, and high-titer anti-MAG antibodies (table). His symptoms transiently improved with oral corticosteroids and IVIG. Over the following 7 years, he received 5 courses of rituximab, $2 \mathrm{~g}$ every year. His gait and stamina improved after the first 2 treatments, but there was no further benefit. He gradually progressed with more weakness, requiring MAFOs and canes for ambulation, and prominent hand tremors. The IgMr spike and

\author{
Correspondence \\ Dr. Dalakas \\ marinos.dalakas@jefferson.edu
}

\section{MORE ONLINE}

$\rightarrow$ Class of Evidence

Criteria for rating therapeutic and diagnostic studies

NPub.org/coe 
Table IgM levels and anti-MAG antibody titers before and after treatment with obinutuzumab in 2 patients with anti-MAG neuropathy

\begin{tabular}{|c|c|c|c|}
\hline Patients & $\begin{array}{l}\text { IgM levels } \\
\text { (normal } 40-230 \mathrm{mg} / \mathrm{dL} \text { ) }\end{array}$ & $\begin{array}{l}\text { IgM monoclonal } \\
\text { spike }\end{array}$ & $\begin{array}{l}\text { Anti-MAG titers by EIA } \\
\text { (normal } \leq 1: 1600 \text { units) }\end{array}$ \\
\hline \multicolumn{4}{|l|}{ Patient 1} \\
\hline Before obinutuzumab & $524 \mathrm{mg} / \mathrm{dL}$ & Present & $>1: 102,400$ \\
\hline After obinutuzumab & $229 \mathrm{mg} / \mathrm{dL}$ & Present & $<1: 1,600$ (normalized) \\
\hline \multicolumn{4}{|l|}{ Patient 2} \\
\hline Before obinutuzumab & $420 \mathrm{mg} / \mathrm{dL}$ & Present & $>1: 102,400$ \\
\hline After obinutuzumab & 173 mg/dL & Present & $<1: 1,600$ (normalized) \\
\hline
\end{tabular}

high anti-MAG antibody titers persisted. Because of severe disease worsening and continuing disability not responding anymore to rituximab, he was treated with obinutuzumab, administered for 6 months as described above.

\section{Results}

There was no clinical improvement or worsening in the patients' neuropathic symptoms 6 and 12 months after treatment with obinutuzumab. In patient 1 , the neurologic deficits remained unchanged several months after therapy. Patient 2, 1 year after therapy, showed signs of progression in pace consistent with his pretreatment course; no accelerated worsening related to obinutuzumab was observed. Both patients tolerated the treatment well. Except for transient mild thrombocytopenia, there were no complications during the administration or the follow-up period.

Despite no clinical benefits, however, the IgM levels normalized and remained normal up to a year after obinutuzumab in both patients (table). Of interest, the anti-MAG antibody titers, 6 months after treatments, were also normalized and remained

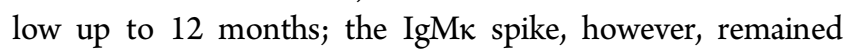
unchanged without discernible differences in the light chain (table). In patient 2, 1 year after obinutuzumab, the anti-MAG titers started to rise, reaching now $>70,000$ units.

\section{Discussion}

The clinical success of first-generation glycoengineered type-I, anti-CD20-mediated, B-cell-depleting, monoclonal antibodies in autoimmune neurologic and rheumatological disorders has provided the rationale for using more potent next-generation anti-CD20 agents. For example, ocrelizumab and ofatumumab seem more effective than rituximab in progressive and relapsing MS. ${ }^{5,6}$ Obinutuzumab, a third-generation, glycoengineered type-II, humanized anti-CD20 monoclonal antibody approved for CLL, has increased binding affinity to the $\mathrm{Fc}$ receptor on $\mathrm{B}$ cells and enhanced complement and antibody-dependent cytotoxicity resulting in extensive B-cell lysis of peripheral $\mathrm{B}$ cells, including some within the lymphoid tissues; because it also affects IL-6 production, it is expected to cause more sustained depletion of memory B cells and affect antibody production. These effects prompted us to evaluate its efficacy in patients with rituximab-refractory anti-MAG-mediated neuropathy. ${ }^{3}$ Obinutuzumab, administered for 6 months, was safe but did not improve the patients' symptomatology even up to a year of follow-up. In contrast to rituximab, however, it normalized the IgM level and anti-MAG antibody titers (table). This observation suggests an effect beyond B-cell depletion; $B$ cells play a key role in antigen presentation, complement activation, and cytokine production, such as IL-1, IL-6, and IL10 , that affect immunoregulatory $\mathrm{B}$ and $\mathrm{T}$ cells and antibody production by plasma cells. ${ }^{7}$ These preliminary results, even in a limited number of 2 patients, suggest that the IgM anti-MAG antibodies, despite being pathogenic, ${ }^{8}$ do not seem to correlate with clinical response. Whether this is related to our patients' advanced disease and severe axonal degeneration or to ineffectiveness of obinutuzumab is unclear. The good tolerance of the drug, however, the more profound induction of B-cell depletion, and effect on antibodies, as demonstrated with normalization of IgM and anti-MAG titers, suggest that obinutuzumab might still be considered as an early treatment of this difficult-to-treat neuropathy.

\section{Author contributions}

Dr. Rakocevic and Dr. Martinez: study concept and design, acquisition of data, analysis and interpretation, and critical revision of the manuscript for important intellectual content. Dr. Dalakas: study concept and design, analysis and interpretation, critical revision of the manuscript for important intellectual content, and study supervision.

\section{Study funding}

No targeted funding reported.

\section{Disclosure}

M. Dalakas served on the scientific advisory board of Novartis, Baxalta, and Octapharma; received travel funding and/or speaker honoraria from Merck/Serono, Octapharma, and Pfizer AG; served on the editorial board of/as an editor of Neurology, BMC Neurology, Acta Myologica, Acta Neurologica 
Scandinavica, and Therapeutic Advances in Neurology; consulted for Therapath, Baxter, Octapharma, CSL, and the Dysimmune Diseases Foundation; received institutional support to Thomas Jefferson University and University of Athens from Merck Serono, Genzyme, Novartis, the GuillainBarré Syndrome/CIDP Foundation, Dysimmune Diseases Foundation, CSL, Biogen, and Newfactor; G. Rakocevic reports no disclosures. U. Martinez-Outschoorn served on the editorial board of the American Journal of Pathology; received research support from Otsuka Pharmaceuticals and the NIH/ NCI. Full disclosure form information provided by the authors is available with the full text of this article at Neurology.org/NN.

Received January 8, 2018. Accepted in final form March 5, 2018.

\section{References}

1. Dalakas MC, Rakocevic G, Salajegheh M, et al. Placebo-controlled trial of rituximab in IgM anti-myelin-associated glycoprotein antibody demyelinating neuropathy. Ann Neurol 2009;65:286-293.

2. Ferfoglia R, Guimarães-Costa R, Viala K, et al. Long-term efficacy of rituximab in IgM anti-myelin-associated glycoprotein neuropathy: RIMAG follow-up study. J Peripher Nerv Syst 2016;21:10-14.

3. Dalakas MC. Rituximab an anti-MAG neuropathy: more evidence for efficacy and more predictive factors. J Neurol Sci 2017;377:224-226.

4. Dalakas MC. B cells as therapeutic targets in autoimmune neurological disorders. Nat Clin Pract Neurol 2008;4:557-567.

5. Montalban X, Hauser SL, Kappos L, et al. Ocrelizumab versus placebo in primary progressive multiple sclerosis. N Engl J Med 2017;376:209-220.

6. Bar-Or A, Grove R, Austin D, et al. The MIRROR Study: a randomized, double-blind, placebo-controlled, parallel-group, dose-ranging study to investigate the safety and MRI efficacy of subcutaneous ofatumumab in subjects with relapsing-remitting multiple sclerosis. Neurology 2014;82:S23.006.

7. Li R, Rezk A, Healy LM, et al. Cytokine-defined B cell responses as therapeutic targets in multiple sclerosis. Front Immunol 2015;6:626.

8. Latov N. Pathogenesis and therapy of neuropathies associated with monoclonal gammopathies. Ann Neurol 1995;37:S32-S42. 


\section{Neurology \\ Neuroimmunology \& Neuroinflammation}

Obinutuzumab, a potent anti-B-cell agent, for rituximab-unresponsive IgM anti-MAG neuropathy

Goran Rakocevic, Ubaldo Martinez-Outschoorn and Marinos C. Dalakas

Neurol Neuroimmunol Neuroinflamm 2018;5;

DOI 10.1212/NXI.0000000000000460

This information is current as of April 5, 2018

Neurol Neuroimmunol Neuroinflamm is an official journal of the American Academy of Neurology.

Published since April 2014, it is an open-access, online-only, continuous publication journal. Copyright

Copyright $\odot 2018$ The Author(s). Published by Wolters Kluwer Health, Inc. on behalf of the American

Academy of Neurology.. All rights reserved. Online ISSN: 2332-7812.

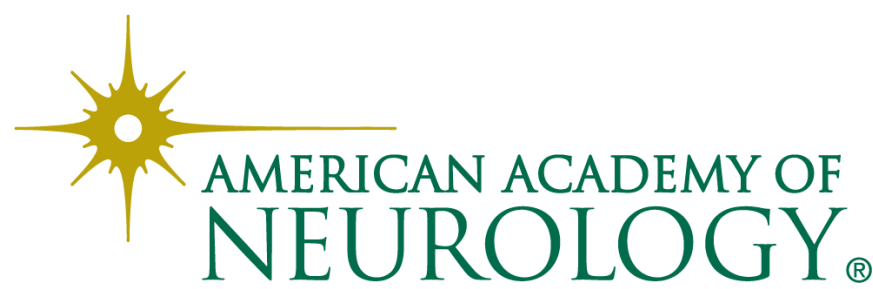




\section{Updated Information \& Services}

References

Citations

Subspecialty Collections

Permissions \& Licensing

Reprints including high resolution figures, can be found at: http://nn.neurology.org/content/5/4/e460.full.html

This article cites 8 articles, 0 of which you can access for free at: http://nn.neurology.org/content/5/4/e460.full.html\#\#ref-list-1

This article has been cited by 3 HighWire-hosted articles: http://nn.neurology.org/content/5/4/e460.full.html\#\#otherarticles

This article, along with others on similar topics, appears in the following collection(s):

All Immunology

http://nn.neurology.org//cgi/collection/all_immunology

Autoimmune diseases

http://nn.neurology.org//cgi/collection/autoimmune_diseases

\section{Class IV}

http://nn.neurology.org//cgi/collection/class_iv

Peripheral neuropathy

http://nn.neurology.org//cgi/collection/peripheral_neuropathy

Information about reproducing this article in parts (figures,tables) or in its entirety can be found online at:

http://nn.neurology.org/misc/about.xhtml\#permissions

Information about ordering reprints can be found online:

http://nn.neurology.org/misc/addir.xhtml\#reprintsus

Neurol Neuroimmunol Neuroinflamm is an official journal of the American Academy of Neurology.

Published since April 2014, it is an open-access, online-only, continuous publication journal. Copyright

Copyright $\odot 2018$ The Author(s). Published by Wolters Kluwer Health, Inc. on behalf of the American

Academy of Neurology.. All rights reserved. Online ISSN: 2332-7812.

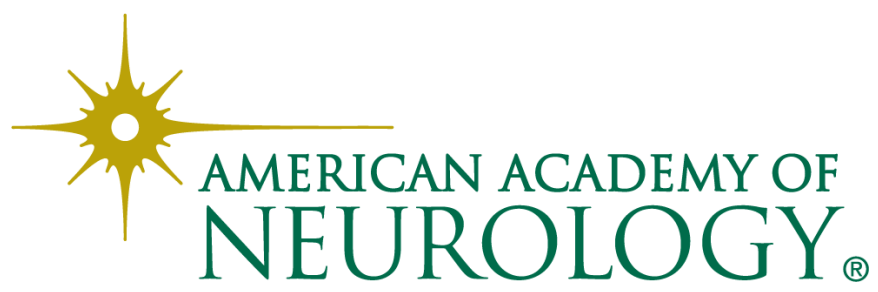

